\title{
Pembuatan dan Pengujian Stabilitas Bubuk Pewarna Alami dari Daun Bayam Merah (Alternanthera amoena Voss.)
}

\author{
Niken Ayu Permatasari*, Fitri Afifah \\ PS Teknologi Industri Pertanian, Fakultas Teknologi Pertanian, IPB University
}

Diterima 26 Juni 2020/ Disetujui 07 Agustus 2020

\begin{abstract}
Redleaf amarant (Alternanthera amoena Voss.) is a kind of leaf that used as natural dye because its composition consists anthocyanin which produce red color in low $\mathrm{pH}$ condition. The aims of this research was to produce natural dye powder from readleaf amaranth and to test its stabilized during the storage. The experimental design that used Completed Randomized Design (CRD) with two factors were concentration of maltodextrin $(15 \%, 20 \%, 25 \%)$ and the solvent (aquadest, aquadest $+\mathrm{HCl} 1 \%$, aquadest + citric acid 5\%). The result showed that the best treatment of natural dye powder from redleaf amaranth was found in the addition of maltodextrin concentration of $15 \%$ and aquadest + citric acid $5 \%$ with resulted in yield of 15,69\%, moisture content 4,36\%, total anthocyanin 0,587 $\mathrm{mg} / \mathrm{g}$ substance, 99,00\% of solubility, and ${ }^{0} \mathrm{Hue} 6,34$ (red-purple). The higher concentrations of maltodextrin caused higher yield and solubility that resulted, the lower moisture content and total of anthocyanin, and also paler color that resulted. The testing of the stability of natural dye powder to light, $\mathrm{pH}$, and temperature produces a good stability and a less significant quality reduction until day 10. The longer the storage caused higher moisture content, the lower solubility and total antocyanin, and paler color that resulted. Key words: anthocyanin, maltodextrin, natural dye powder, redleaf amarant
\end{abstract}

\footnotetext{
*Korespondensi Penulis:

Email : nikenayu@apps.ipb.ac.id
} 


\section{PENDAHULUAN}

Penggunaan warna sintetik saat ini semakin berkembang, namun penggunaan pewarna sintetik seringkali menimbulkan masalah kesehatan (Ernawati 2010). Keadaan tersebut menimbulkan berkembangnya penggunaan pewarna alami yang berasal dari bahan alam. Pigmen alami tersebut banyak ditemukan pada tumbuhan. Bagian tumbuhan yang biasanya memiliki pigmen yang dapat dimanfaatkan sebagai pewarna makanan adalah bagian daun, bunga, dan batang. Selain berfungsi sebagai pewarna, pigmen alami ini juga berfungsi sebagai flavour, antioksidan, antimikroba, dan lainnya (Winarno 2002). Salah satu tanaman yang dapat dimanfaatkan sebagai pewarna alami adalah daun bayam merah (Alternanthera amoena Voss).

Daun bayam merah mengandung pigmen antosianin. Antosianin merupakan pigmen alami yang dapat menghasilkan warna biru, ungu, violet, magenta, merah, dan kuning. Antosianin menimbulkan warna merah pada $\mathrm{pH}$ rendah (2-4), sedangkan pada pH tinggi dapat menghasilkan warna kuning, biru, bahkan tidak berwarna. Antosianin stabil dengan warna merah pada $\mathrm{pH} 3,5$ dan suhu $50^{\circ} \mathrm{C}$ mempunyai berat molekul 207,08 gram/mol (Armanzah dan Hendrawati 2016).

Pewarna alami umumnya dalam bentuk konsentrat, namun pewarna dengan bentuk konsentrat memiliki beberapa kelemahan yaitu ekstrak pewarna alami yang dihasilkan harus langsung digunakan, stabilitas yang rendah dan memiliki umur simpan yang tidak lama (Tama et al., 2014). Oleh karena itu perlu dilakukan pembuatan pewarna alami dari daun bayam merah dalam bentuk yang lebih stabil yaitu dalam bentuk bubuk. Kelebihan pewarna alami dalam bentuk bubuk diantaranya adalah memiliki kadar air yang rendah, umur simpan yang lebih lama, praktis dalam penggunaan, dan kemudahan penanganan, transportasi, dan penyimpanan.
Metode pembuatan bubuk pewarna alami yang digunakan dalam penelitian ini adalah pengeringan vakum (vacuum drying). Pengeringan vakum adalah suatu sistem pengeringan bahan dengan memanfaatkan keadaan vakum. Metode pengeringan ini sesuai untuk bahan yang memiliki sensitivitas terhadap suhu (Sutanto 2007). Menurut Ernawati (2010), metode mikroenkapsulasi juga digunakan untuk membuat sediaan pewarna dalam bentuk yang lebih stabil. Metode mikroenkapsulasi yang digunakan antara lain spray drying dan tray drying.

Pembuatan produk bubuk dilakukan dengan cara menambahkan bahan pengisi maltodekstrin agar menambah volume dan berat bubuk yang dihasilkan dan mempercepat pengeringan (Gonnissen et al. 2008). Kelebihan maltodekstrin adalah mudah larut dalam air dingin dan maltodekstrin bersifat mengalami dispersi cepat, memiliki sifat daya larut yang tinggi dan sifat higroskopis yang rendah. Selain maltodekstrin, bahan pengisi yang sering digunakan adalah desktrin. Perbedaan antara dekstrin dengan maltodekstrin terletak pada nilai Dextrose Equivalent (DE). Menurut Wulansari et al., (2012), Dextrose Equivalent (DE) maltodekstrin 3-20 lebih besar dari DE dekstrin yakni 3-5. Menurut Eko (2008), semakin tinggi nilai DE, maka kandungan monosakarida semakin tinggi, menyebabkan daya ikatnya semakin besar, sehingga penggunaan maltodekstrin menyebabkan kadar airnya semakin tinggi dibandingkan dengan dekstrin.

Oleh karena itu, penelitian ini mengkaji tentang pembuatan bubuk pewarna alami dari bayam merah dan menguji kestabilannya selama penyimpanan. Penelitian ini diharapkan dapat meningkatkan nilai tambah bayam merah dengan memanfaatkannya sebagai bubuk pewarna alami dengan kualitas baik dan stabil selama penyimpanan.

\section{METODOLOGI PENELITIAN}




\section{Bahan}

Bahan yang digunakan dalam penelitian ini adalah daun bayam merah yang diperoleh dari kebun Agribusiness Development Station (ADS) Bogor, maltodekstrin toko kimia Setia Guna Bogor, akuades, $\mathrm{HCl}$, dan asam sitrat. Bahan yang digunakan untuk analisis adalah akuades, larutan buffer $\mathrm{KCl}$, larutan buffer Na-Asetat, larutan buffer $\mathrm{pH} 3, \mathrm{pH} 5, \mathrm{pH} 7, \mathrm{pH}$ 9, plastik $\mathrm{PP}$ dan aluminium foil.

\section{Alat}

Alat yang digunakan pada pembuatan bubuk pewarna alami adalah timbangan digital, timbangan analitik, blender, baskom, gelas ukur, beaker glass, pipet tetes, pengaduk, erlenmeyer, sudip, kain saring, kertas saring, corong, stirer, magnetic stirer, sentrifuge, dan vacuum dryer. Alat yang digunakan untuk analisis adalah oven, timbangan digital, cawan aluminium, desikator, gegep, gelas ukur, kuvet, spektrofotometer UV-VIS, colorimeter, pompa vakum, kertas saring Whatman No.42, corong, sudip, gelas piala, erlenmeyer, pipet mikro, tabung ulir, pipet volumetrik, dan bulb.

\section{Analisis bubuk pewarna alami daun bayam merah}

Analisis bubuk pewarna alami dilakukan untuk menentukan perlakuan terbaik dalam pembuatan bubuk pewarna alami. Analisis yang dilakukan meliputi rendemen, kadar air, total antosianin, kelarutan, dan warna.

\section{Pengujian stabilitas bubuk pewarna alami} Pengujian stabilitas bubuk pewarna alami dilakukan pada bubuk pewarna alami dari hasil perlakuan terbaik. Pengujian stabilitas yang dilakukan berdasarkan tiga parameter pengujian yaitu terhadap cahaya (terang dan gelap), $\mathrm{pH}$ ( $\mathrm{pH} 3, \mathrm{pH} 5, \mathrm{pH} 7$, dan $\mathrm{pH}$ 9), dan suhu penyimpanan (suhu $4^{\circ} \mathrm{C}$, suhu ruang, dan suhu $50^{\circ} \mathrm{C}$ ).

\section{Rancangan Percobaan}

Rancangan percobaan yang digunakan dalam penelitian pembuatan dan pengujian stabilitas bubuk pewarna alami dari daun bayam merah adalah Rancangan Acak Lengkap (RAL) dengan dua faktor dan dilakukan dua ulangan, faktor I yaitu konsentrasi maltodekstrin $(15 \%, 20 \%, 25 \%)$ dan faktor II yaitu jenis pelarut (akuades, akuades+ $\mathrm{HCl}$ $1 \%$, dan akuades+asam sitrat 5\%). Analisa data menggunakan analisa ragam (ANOVA) dengan selang kepercayaan 95\%. Uji lanjut yang digunakan adalah Duncan's Multi Range Test (DMRT).

\section{HASIL DAN PEMBAHASAN}

\section{Pembuatan Bubuk Pewarna Alami}

Pembuatan bubuk pewarna alami dengan perbandingan daun bayam merah dengan pelarut yaitu 1:3 menghasilkan filtrat berwarna merah keunguan yang pekat, filtrat yang kental, dan ampas yang dihasilkan tidak terlalu banyak. Filtrat yang dihasilkan dari beberapa jenis pelarut memberikan hasil yang berbeda-beda yaitu untuk filtrat dengan akuades $+\mathrm{HCl} 1 \%$ menghasilkan warna yang lebih pekat dibandingkan dengan pelarut akuades dan akuades+asam sitrat 5\%. Hal ini disebabkan pelarut mengandung asam kuat sehingga menghasilkan zat antosianin berwarna merah lebih banyak. Menurut Armanzah dan Hendrawati (2016), antosianin menghasilkan warna merah pada $\mathrm{pH}$ rendah (2-4). Semakin rendah $\mathrm{pH}$ maka menghasilkan warna merah yang semakin pekat.

Peningkatan konsentrasi maltodekstrin menyebabkan kekentalan larutan semakin meningkat disebabkan oleh sifat maltodekstrin sebagai bahan pengisi dan pengental walaupun viskositas maltodekstrin cenderung rendah. Menurut Pentury et al. (2013), viskositas maltodekstrin berkisar antara 6-49 cP.

\section{Analisis Bubuk Pewarna Alami}




\section{Rendemen}

Rendemen bubuk pewarna alami dari daun bayam merah berkisar antara 8-21\%.
Hasil rendemen bubuk pewarna alami dari daun bayam merah dapat dilihat pada Gambar 2.

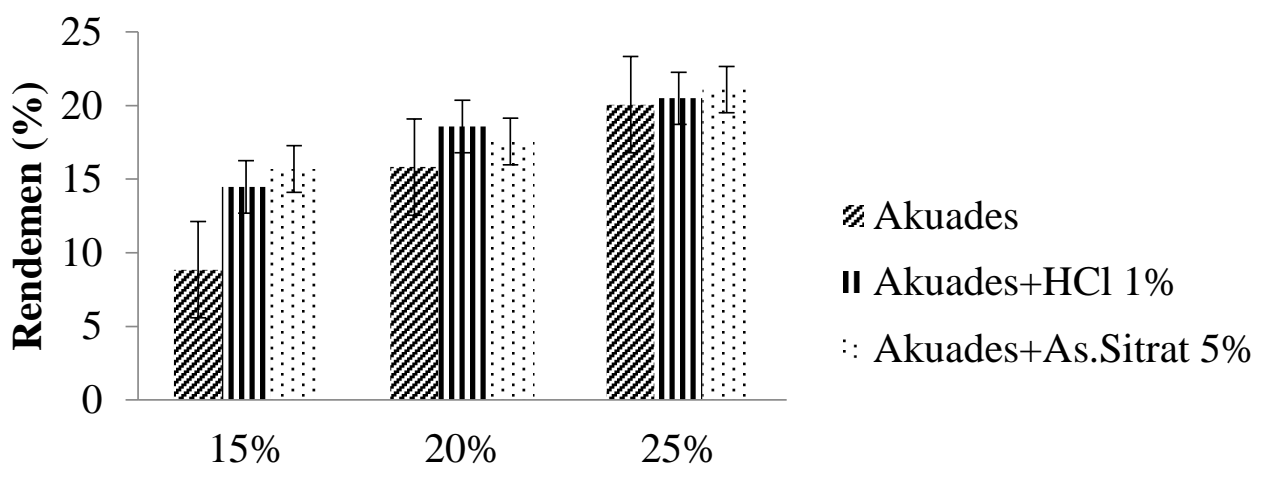

Konsentrasi Maltodekstrin

Gambar 1 Rendemen bubuk pewarna alami

Berdasarkan Gambar 2 tersebut, terlihat bahwa rendemen tertinggi diperoleh pada perlakuan campuran pelarut akuades+asam sitrat 5\% dan penambahan konsentrasi maltodekstrin sebesar $25 \%$ dengan rendemen sebesar $21,08 \%$. Filtrat dengan penambahan konsentrasi maltodekstrin sebesar $25 \%$ menghasilkan rendemen bubuk pewarna alami lebih tinggi dibandingkan konsentrasi $15 \%$ dan $20 \%$. Menurut Endang dan Prasetyastuti (2010), peningkatan rendemen dipengaruhi oleh banyaknya jumlah maltodekstrin yang ditambahkan. Semakin banyak maltodekstrin yang ditambahkan maka semakin tinggi rendemen yang dihasilkan. Hal ini disebabkan sifat maltodekstrin sebagai bahan pengisi dapat meningkatkan rendemen produk akhir.

Berdasarkan hasil analisis statistik, perlakuan jenis pelarut dan penambahan konsentrasi maltodekstrin memberikan pengaruh yang berbeda nyata $(\alpha=5 \%)$ terhadap rendemen. Interaksi antar kedua perlakuan juga memberikan pengaruh yang signifikan. Hasil uji lanjut DMRT menunjukkan bahwa seluruh perlakuan memberikan pengaruh nyata terhadap parameter rendemen. Perlakuan jenis pelarut akuades+asam sitrat 5\% dengan penambahan konsentrasi maltodekstrin sebesar $25 \%$ menghasilkan rendemen paling tinggi.

\section{Kadar Air}

Kadar air bubuk pewarna alami dari daun bayam merah yang dihasilkan berkisar antara 3-7\%. Hasil kadar air bubuk pewarna alami dari daun bayam merah dapat dilihat pada Gambar 3.

Berdasarkan Gambar 3 tersebut, dapat dilihat bahwa kadar air terendah diperoleh pada perlakuan campuran pelarut akuades dengan asam sitrat $5 \%$ dan penambahan konsentrasi maltodekstrin sebesar 25\%, sehingga diperoleh kadar air sebesar 3,21\%. Menurut Utomo (2013), penambahan maltodekstrin dapat meningkatkan total padatan pada bahan yang akan dikeringkan. Semakin banyak maltodekstrin yang ditambahkan maka semakin rendah kadar air yang diperoleh. Hal ini disebabkan karena salah satu sifat maltodekstrin dapat mengikat kadar air bebas suatu bahan sehingga dengan penambahan maltodekstrin yang semakin banyak dapat menurunkan kadar air produk.

Berdasarkan hasil analisis statistik, perlakuan jenis pelarut dan penambahan konsentrasi maltodekstrin memberikan pengaruh yang berbeda nyata $(\alpha=5 \%)$ 
terhadap kadar air sedangkan interaksi antar kedua perlakuan tidak memberikan pengaruh yang nyata. Hasil uji lanjut DMRT menunjukkan bahwa seluruh perlakuan memberikan pengaruh nyata terhadap parameter kadar air. Perlakuan jenis pelarut akuades+asam sitrat 5\% dengan penambahan konsentrasi maltodekstrin sebesar $25 \%$ menghasilkan kadar air paling rendah.

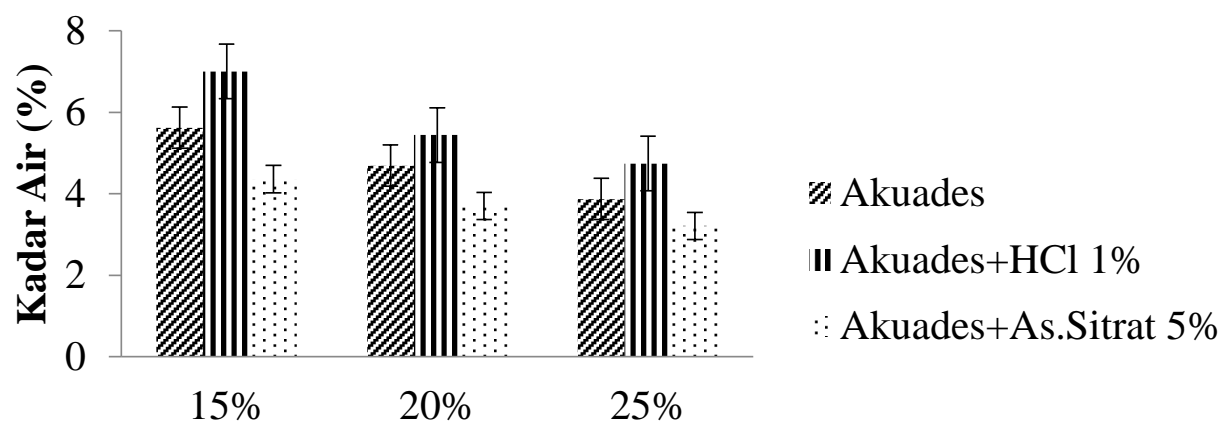

Konsentrasi Maltodekstrin

Gambar 2 Kadar air bubuk pewarna alami

\section{Total Antosianin}

Bubuk pewarna alami dari daun bayam merah setelah dilakukan pengeringan akan mengalami penurunan total antosianin disebabkan oleh proses pengeringan dengan suhu yang cukup tinggi sehingga terjadi degradasi antosianin. Penggunaan pengeringan vakum dapat meminimalisir degradasi antosianin dan cocok digunakan untuk bahan yang memiliki sensitivitas terhadap suhu. Total antosianin yang dihasilkan bubuk pewarna alami dari daun bayam merah berkisar antara 0,300-0,750 $\mathrm{mg} / \mathrm{g}$ bahan. Hasil analisis total antosianin bubuk pewarna alami dari daun bayam merah dapat dilihat pada Gambar 4.

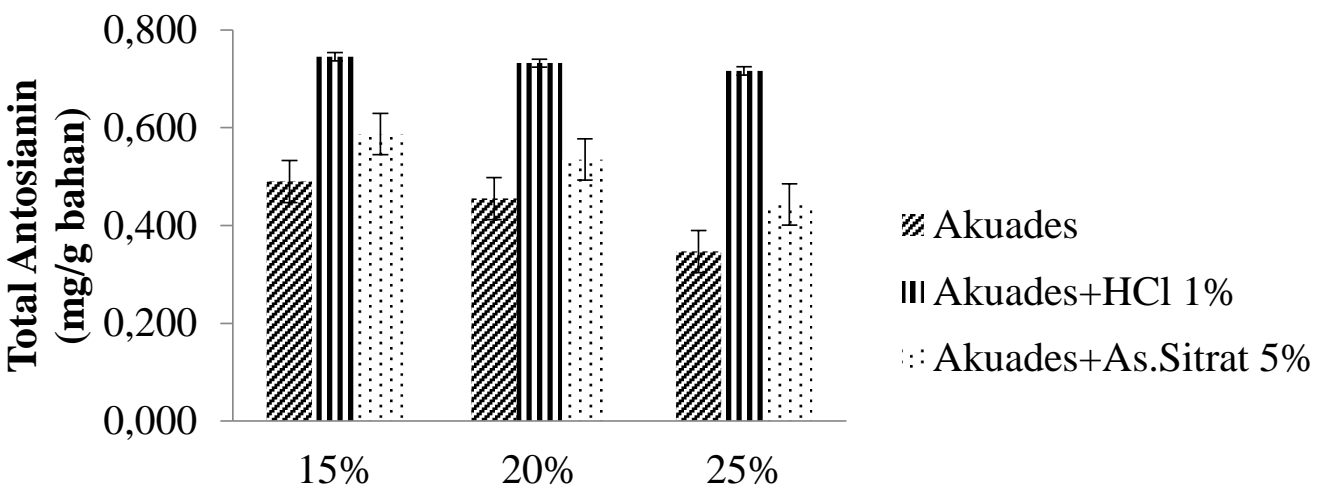

\section{Konsentrasi Maltodekstrin}

Gambar 3 Total antosianin bubuk pewarna alami

Berdasarkan Gambar 4 tersebut, dapat dilihat bahwa total antosianin tertinggi diperoleh pada perlakuan campuran pelarut akuades dengan $\mathrm{HCl} 1 \%$ dan penambahan konsentrasi maltodekstrin sebesar $15 \%$, sehingga diperoleh total antosianin sebesar
$0,745 \mathrm{mg} / \mathrm{g}$ bahan. Perbedaan total antosianin dapat dipengaruhi oleh jenis pelarut yang digunakan dan konsentrasi penambahan maltodekstrin. Antosianin dapat menghasilkan warna merah pada kondisi $\mathrm{pH}$ yang asam. Kondisi pelarut yang semakin 
asam dapat menyebabkan banyaknya dinding sel vakuola daun yang pecah sehingga pigmen antosianin yang terekstraksi semakin banyak (Hayati et al. 2012).

Berdasarkan hasil analisis statistik, perlakuan jenis pelarut dan penambahan konsentrasi maltodekstrin memberikan pengaruh yang berbeda nyata $(\alpha=5 \%)$ terhadap total antosianin. Interaksi antar kedua perlakuan juga memberikan pengaruh yang signifikan. Hasil uji lanjut DMRT menunjukkan bahwa seluruh perlakuan memberikan pengaruh nyata terhadap parameter total antosianin. Perlakuan jenis pelarut akuades $+\mathrm{HCl} \quad 1 \%$ dengan penambahan konsentrasi maltodekstrin sebesar $15 \%$ menghasilkan total antosianin paling tinggi.

\section{Kelarutan}

Tingginya kelarutan bubuk pewarna alami ini disebabkan oleh sifat bahan pengisi maltodekstrin yang dapat larut dalam air. Hasil analisis kelarutan bubuk pewarna alami dari daun bayam merah dapat dilihat pada Gambar 5.

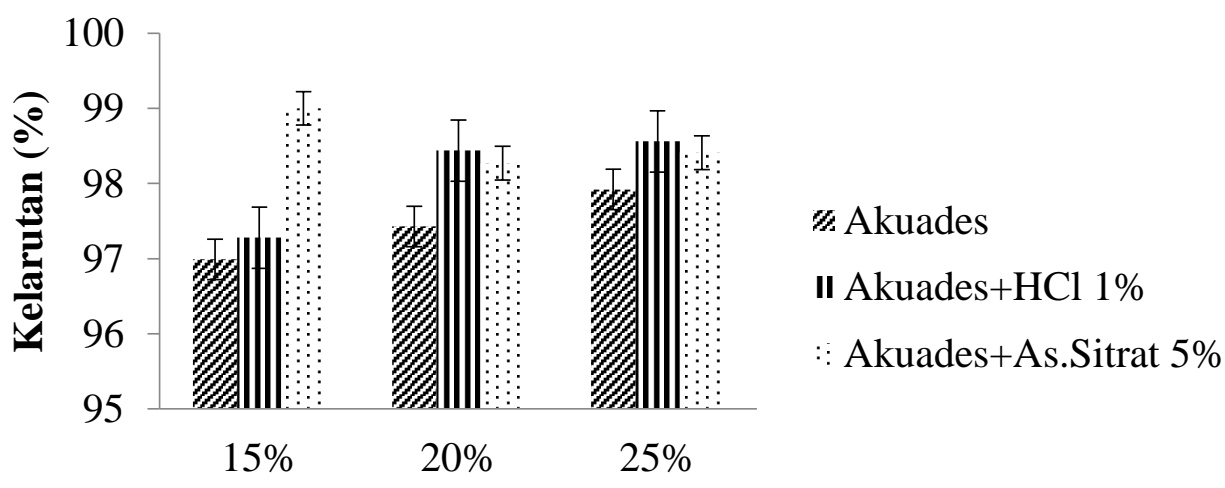

\section{Konsentrasi Maltodekstrin}

Gambar 4 Kelarutan bubuk pewarna alami

Kelarutan tertinggi diperoleh pada perlakuan campuran pelarut akuades+asam sitrat $5 \%$ dan penambahan konsentrasi maltodekstrin sebesar 15\%, sehingga diperoleh kelarutan sebesar 99,00\%. Perbedaan kelarutan ini disebabkan oleh perbedaan kadar air bubuk pewarna alami. Semakin tinggi kadar air bubuk pewarna maka semakin sulit bubuk pewarna tersebut larut dalam air sehingga menyebabkan kelarutan bubuk pewarna rendah.

Berdasarkan hasil analisis statistik, menunjukkan bahwa perlakuan jenis pelarut dan penambahan konsentrasi maltodekstrin memberikan pengaruh yang berbeda nyata ( $\alpha$ $=5 \%$ ) terhadap kelarutan. Interaksi antar kedua perlakuan juga memberikan pengaruh yang berbeda nyata. Hasil uji lanjut DMRT menunjukkan bahwa seluruh perlakuan memberikan pengaruh nyata terhadap parameter kelarutan.

\section{Warna}

Analisis warna bubuk pewarna alami dari daun bayam merah dilakukan dengan menggunakan alat colorimeter dan menghasilkan nilai L, a, b, dan ${ }^{0}$ Hue. Nilai L menunjukkan kecerahan, a dan $b$ adalah koordinat-koordinat kromatisitas, dimana a untuk warna hijau (a negatif) ke merah (a positif), b untuk warna biru (b negatif) sampai kuning (b positif) dan ${ }^{0}$ Hue menujukkan warna sampel yang dihasilkan (Francis 1999).

Hasil analisis warna bubuk pewarna alami dari daun bayam merah dengan menggunakan alat colorimeter dapat dilihat pada Tabel 1 .

Warna bubuk pewarna alami daun 
bayam merah berdasarkan tabel tersebut sebagian besar menghasilkan warna merah keunguan dengan nilai ${ }^{0}$ Hue yang berada pada rentang $342^{0}-18^{0}$. Jenis pelarut asam akan menghasilkan warna bubuk pewarna lebih pekat dan gelap dibandingkan pelarut akuades. Hal ini disebabkan sifat antosianin yang dapat menghasilkan warna merah pada kondisi yang asam. Semakin tinggi konsentrasi maltodekstrin maka semakin pudar warna yang dihasilkan bubuk pewarna.

Berdasarkan hasil analisis rendemen, kadar air, total antosianin, kelarutan, dan warna maka perlakuan terbaik dalam pembuatan bubuk pewarna alami dari daun bayam merah menggunakan jenis pelarut akuades+asam sitrat 5\% dengan penambahan konsentrasi maltodekstrin sebesar $15 \%$. Perlakuan tersebut menghasilkan rendemen sebesar $15,69 \%$, kadar air 4,36\%, total antosianin $0,587 \mathrm{mg} / \mathrm{g}$ bahan, kelarutan 99,00\%, dan warna dengan nilai ${ }^{0}$ Hue 6,34 (merah-ungu). Penentuan perlakuan terbaik ini berdasarkan atas nilai rendemen yang cukup tinggi dengan nilai kadar air kurang dari $10 \%$ sesuai dengan penelitian Wibawanto et al. (2014) mengenai produksi serbuk pewarna alami bit merah. Selain itu, total antosianin yang diperoleh dari perlakuan ini cukup tinggi karena menggunakan pelarut asam dan konsentrasi penambahan maltodekstrin yang lebih rendah sehingga menghasilkan warna bubuk yang baik dan lebih pekat. Kelarutan yang diperoleh pada perlakuan ini juga cukup tinggi mencapai 99\% dibandingkan dengan perlakuan lainnya. Perlakuan terbaik dari tahap ini, dilanjutkan dengan uji stabilitas bubuk pewarna alami.

Tabel 1 Uji warna bubuk pewarna alami

\begin{tabular}{cccccc}
\hline Perlakuan & $\mathbf{L}$ & $\mathbf{a}$ & $\mathbf{b}$ & ${ }^{\mathbf{0}}$ Hue & Warna \\
\hline A1B1 & 53,52 & 35,48 & 2,59 & 4,28 & Merah-ungu \\
A1B2 & 59,61 & 38,35 & $-1,91$ & 357,00 & Merah-ungu \\
A1B3 & 65,67 & 23,31 & 4,60 & 10,78 & Merah-ungu \\
A2B1 & 47,24 & 16,68 & 4,84 & 16,49 & Merah-ungu \\
A2B2 & 49,33 & 17,28 & 7,23 & 23,24 & Merah \\
A2B3 & 48,70 & 19,37 & 11,53 & 30,73 & Merah \\
A3B1 & 51,18 & 30,10 & 3,46 & 6,34 & Merah-ungu \\
A3B2 & 55,02 & 32,45 & 7,19 & 12,24 & Merah-ungu \\
A3B3 & 62,83 & 27,84 & 12,21 & 23,58 & Merah \\
\hline
\end{tabular}

Keterangan :
A1 = Akuades
$\mathrm{B} 1=$ Maltodekstrin $15 \%$
$\mathrm{A} 2=$ Akuades $+\mathrm{HCl} 1 \%$
B2 $=$ Maltodekstrin 20\%
A3 $=$ Akuades + As. Sitrat 5\%
B3 = Maltodekstrin 25\%

\section{Uji Stabilitas Bubuk Pewarna Alami}

Pengujian stabilitas yang dilakukan selama 10 hari pengamatan berdasarkan tiga perlakuan pengujian yaitu terhadap cahaya (terang dan gelap), $\mathrm{pH}$ ( $\mathrm{pH} 3, \mathrm{pH} 5, \mathrm{pH} 7$, dan $\mathrm{pH} 9)$, dan suhu penyimpanan $\left(4^{\circ} \mathrm{C}, 25^{\circ} \mathrm{C}\right.$, dan $\left.50^{\circ} \mathrm{C}\right)$. Pengujian stabilitas bubuk pewarna alami ini menggunakan kemasan PP
(Polipropilen) tebal dengan ketebalan 0,1 cm.

\section{Stabilitas terhadap cahaya}

Hasil pengujian stabilitas terhadap cahaya untuk parameter kadar air, total antosianin, kelarutan, dan warna bubuk pewarna alami dapat dilihat pada Tabel 2. 
Tabel 2 Uji stabilitas bubuk pewarna alami terhadap cahaya

\begin{tabular}{ccccccccc}
\hline \multirow{2}{*}{$\begin{array}{c}\text { Hari } \\
\text { ke- }\end{array}$} & \multicolumn{2}{c}{ Kadar air $(\%)$} & \multicolumn{2}{c}{ Kelarutan $(\%)$} & \multicolumn{2}{c}{$\begin{array}{c}\text { Total antosianin } \\
(\mathbf{m g} / \mathbf{g} \text { bahan) }\end{array}$} & \multicolumn{2}{c}{ Warna $\left({ }^{0} \mathrm{Hue}\right)$} \\
\cline { 2 - 8 } & Terang & Gelap & Terang & Gelap & Terang & Gelap & Terang & Gelap \\
\hline 0 & 4,24 & 4,24 & 98,54 & 98,54 & 0,581 & 0,581 & $27,25($ merah) & $27,25($ merah) \\
2 & 4,43 & 4,68 & 98,22 & 98,02 & 0,559 & 0,569 & 27,17 (merah) & $25,92($ merah) \\
4 & 4,60 & 4,70 & 98,04 & 97,96 & 0,538 & 0,540 & 22,99 (merah) & $20,82($ merah) \\
6 & 4,79 & 5,03 & 97,82 & 97,71 & 0,527 & 0,528 & 16,19 (merah-ungu) & 15,08 (merah-ungu) \\
8 & 5,03 & 5,21 & 97,62 & 97,47 & 0,513 & 0,519 & 10,70 (merah-ungu) & 9,16 (merah-ungu) \\
10 & 5,24 & 5,40 & 97,51 & 97,42 & 0,503 & 0,508 & 1,88 (merah-ungu) & 2,74 (merah-ungu) \\
\hline
\end{tabular}

Keterangan :

${ }^{0}$ Hue $=342^{0}-18^{0}$ (merah keunguan)

${ }^{0}$ Hue $=18^{0}-54^{0}($ merah $)($ Hutching 1999)

\section{Kadar Air}

Hasil pengujian stabilitas untuk parameter kadar air pada Tabel 2 menunjukkan bahwa semakin lama penyimpanan maka kadar air bubuk pewarna alami semakin meningkat, baik bubuk pewarna alami yang disimpan pada cahaya terang maupun cahaya gelap. Hal ini disebabkan semakin lama penyimpanan maka akan semakin tinggi kandungan air yang terkandung pada produk. Kelembaban relatif $(\mathrm{RH})$ pada ruang penyimpanan sebesar $\pm 70-75 \%$. Kelembaban pada ruang penyimpanan akan berpengaruh terhadap kadar air yang dihasilkan. Kadar air pada kondisi gelap lebih tinggi dibandingkan dengan kondisi terang. Kelembaban yang tinggi menyebabkan uap air yang dihasilkan produk pada kondisi gelap lebih tinggi dibandingkan kondisi terang. Menurut Hall (1980), penyimpanan diruang gelap menyebabkan kelembaban produk lebih tinggi dibandingkan ruang terang. Hal ini dikarenakan produk tidak mendapat cukup sinar atau cahaya dari matahari.

\section{Total Antosianin}

Hasil pengujian stabilitas untuk parameter total antosianin pada Tabel 2 menunjukkan bahwa semakin lama penyimpanan maka total antosianin bubuk pewarna alami semakin menurun, baik bubuk pewarna alami yang disimpan pada cahaya terang maupun gelap. Hal ini disebabkan semakin lama penyimpanan maka akan semakin lama produk terkena cahaya sehingga mengakibatkan degradasi antosianin. Terdapat beberapa faktor yang dapat mempengaruhi stabilitas antosianin yaitu $\mathrm{pH}$, cahaya, suhu, konsentrasi, oksigen, pelarut, keberadaan enzim, flavonoid dan ion logam (Ovando et al. 2009).

\section{Kelarutan}

Hasil pengujian stabilitas untuk parameter kelarutan bubuk pewarna alami dapat dilihat pada Tabel 2 menunjukkan bahwa semakin lama penyimpanan maka kelarutan bubuk pewarna alami semakin rendah, baik bubuk pewarna alami yang disimpan pada cahaya terang maupun gelap. Kelarutan produk pada kondisi terang masih lebih tinggi dibandingkan dengan kondisi gelap. Hal ini dapat terjadi karena bubuk pewarna alami pada kondisi terang dapat ditembus oleh cahaya langsung sehingga kadar air yang terdapat pada produk tidak sebanyak pada kondisi gelap. Menurut Ernawati (2010), kelarutan suatu bahan dipengaruhi oleh kadar airnya, semakin tinggi kadar air maka semakin rendah kelarutan suatu bahan karena produk cenderung 
membentuk butiran yang lebih besar tetapi tidak porous. Pada penyimpanan kondisi gelap, kadar air produk lebih rendah dibandingkan penyimpanan kondisi cahaya terang. Apabila kadar air rendah maka kelarutan lebih tinggi dan sebaliknya.

\section{Warna}

Hasil pengujian stabilitas pada analisis warna bubuk pewarna alami dapat dilihat pada Tabel 2 menunjukkan bahwa semakin lama penyimpanan maka warna yang dihasilkan semakin pudar walaupun tidak signifikan perubahannya, baik bubuk pewarna alami yang disimpan pada cahaya terang maupun gelap. Hal ini disebabkan semakin lama penyimpanan maka kandungan zat warna pada bubuk pewarna alami semakin menurun. Antosianin sebagai zat warna yang menghasilkan warna merah menentukan warna yang dihasilkan pada bubuk pewarna alami (Armanzah dan Hendrawati 2016). Nilai ${ }^{0}$ Hue yang dihasilkan pada kondisi terang lebih tinggi dibandingkan kondisi gelap walaupun tidak terlalu signifikan perbedaannya. Hal ini dikarenakan kondisi terang menyebabkan pemudaran warna lebih tinggi dibandingkan kondisi gelap. Warna produk pada kondisi gelap masih lebih pekat dibandingkan dengan kondisi terang. Hal ini disebabkan minimnya cahaya langsung yang dapat tembus ke dalam produk. Menurut Harborne (2005), cahaya mempunyai dua pengaruh yang saling berlawanan terhadap antosianin, yaitu berperan dalam pembentukan antosianin dan cahaya juga berperan dalam laju degradasi warna antosianin, oleh karena itu antosianin harus disimpan di tempat yang gelap dan suhu dingin.

\section{Stabilitas terhadap suhu penyimpanan}

Hasil pengujian stabilitas terhadap suhu penyimpanan untuk parameter kadar air, total antosianin, dan kelarutan bubuk pewarna alami dapat dilihat pada Tabel 3.

Tabel 3 Uji stabilitas bubuk pewarna alami terhadap suhu penyimpanan

\begin{tabular}{cccccccccc}
\hline \multirow{2}{*}{$\begin{array}{c}\text { Hari } \\
\text { ke- }\end{array}$} & \multicolumn{3}{c}{ Kadar Air (\%) } & \multicolumn{3}{c}{ Kelarutan $(\boldsymbol{\%})$} & \multicolumn{3}{c}{$\begin{array}{c}\text { Total Antosianin (mg/g } \\
\text { bahan) }\end{array}$} \\
\cline { 2 - 10 } & $\mathbf{4}^{\mathbf{0}} \mathbf{C}$ & $\mathbf{2 5}^{\mathbf{0}} \mathbf{C}$ & $\mathbf{5 0}^{\mathbf{0}} \mathbf{C}$ & $\mathbf{4}^{\mathbf{0}} \mathbf{C}$ & $\mathbf{2 5}^{\mathbf{0}} \mathbf{C}$ & $\mathbf{5 0}^{\mathbf{0}} \mathbf{C}$ & $\mathbf{4}^{\mathbf{}} \mathbf{C}$ & $\mathbf{2 5}^{\mathbf{0}} \mathbf{C}$ & $\mathbf{5 0} \mathbf{C}$ \\
\hline 0 & 4,24 & 4,24 & 4,24 & 98,54 & 98,54 & 98,54 & 0,581 & 0,581 & 0,581 \\
2 & 4,61 & 4,54 & 4,47 & 98,18 & 98,28 & 98,36 & 0,552 & 0,535 & 0,554 \\
4 & 4,75 & 4,56 & 4,63 & 97,82 & 98,11 & 98,23 & 0,545 & 0,528 & 0,539 \\
6 & 4,95 & 4,96 & 4,85 & 97,74 & 97,68 & 97,99 & 0,537 & 0,512 & 0,524 \\
8 & 5,08 & 5,15 & 4,95 & 97,69 & 97,62 & 97,85 & 0,532 & 0,503 & 0,520 \\
10 & 5,22 & 5,27 & 5,17 & 97,49 & 97,34 & 97,62 & 0,502 & 0,490 & 0,506 \\
\hline
\end{tabular}

\section{Kadar Air}

Hasil pengujian stabilitas untuk parameter kadar air pada Tabel 3 menunjukkan bahwa semakin lama penyimpanan maka kadar air bubuk pewarna alami semakin meningkat, baik bubuk pewarna alami yang disimpan pada suhu $4^{0} \mathrm{C}$, suhu $25^{\circ} \mathrm{C}$ maupun suhu $50^{\circ} \mathrm{C}$. Hal ini disebabkan semakin lama penyimpanan maka akan semakin tinggi kandungan air yang terkandung pada produk. Kelembaban relatif $(\mathrm{RH})$ pada ruang penyimpanan suhu $4^{0} \mathrm{C}$ sebesar $\pm 50 \%$, suhu $25^{\circ} \mathrm{C}$ sebesar \pm 70 75 , dan suhu $50^{\circ} \mathrm{C}$ sebesar $\pm 65 \%$. Kelembaban pada ruang penyimpanan akan berpengaruh terhadap kadar air yang dihasilkan. Kadar air pada suhu $4^{0} \mathrm{C}$ lebih tinggi dibandingkan dengan suhu $25^{\circ} \mathrm{C}$ dan suhu $50^{\circ} \mathrm{C}$ walaupun perbedaannya tidak terlalu signifikan. Hal ini dapat terjadi karena pada suhu $4^{0} \mathrm{C}$ dalam kondisi tertutup dan basah akibat embun air. Semakin rendah 
suhu penyimpanan, maka ada kecenderungan kadar air semakin besar. Hal ini disebabkan oleh pendinginan yang dapat memperlambat kecepatan reaksi-reaksi metabolisme, dimana pada umumnya setiap penurunan suhu $8{ }^{\circ} \mathrm{C}$ kecepatan reaksi akan berkurang menjadi kira-kira setengahnya (Wiersema, 1989).

\section{Total Antosianin}

Hasil pengujian stabilitas untuk parameter total antosianin pada Tabel 3 menunjukkan bahwa semakin lama penyimpanan maka total antosianin bubuk pewarna alami semakin rendah, baik bubuk pewarna alami yang disimpan pada suhu $4^{\circ} \mathrm{C}$, suhu $25^{\circ} \mathrm{C}$ maupun suhu $50^{\circ} \mathrm{C}$. Hal ini disebabkan semakin lama penyimpanan maka akan semakin lama produk terkena cahaya untuk suhu $25^{\circ} \mathrm{C}$ dan terkena panas untuk suhu $50^{\circ} \mathrm{C}$ sehingga mengakibatkan degradasi antosianin. Total antosianin pada suhu $4^{0} \mathrm{C}$ masih lebih tinggi dibandingkan dengan suhu $25^{\circ} \mathrm{C}$ dan suhu $50^{\circ} \mathrm{C}$. Hal ini dapat terjadi karena pada suhu $4^{0} \mathrm{C}$ reaksi pembentukan chalcone cenderung lambat, yang berarti perubahan total antosianin tidak banyak. Chalcone merupakan salah satu senyawa metabolit sekunder golongan flavonoid yang salah satunya terdapat pada antosianin menghasilkan senyawa tidak berwarna pada $\mathrm{pH}$ 5-6 dan perlakuan panas (Ovando et al. 2009).

\section{Kelarutan}

Hasil pengujian stabilitas untuk parameter kelarutan bubuk pewarna alami dapat dilihat pada Tabel 3 menunjukkan bahwa semakin lama penyimpanan maka kelarutan bubuk pewarna alami semakin rendah, baik bubuk pewarna alami yang disimpan pada suhu $4^{0} \mathrm{C}$, suhu $25^{\circ} \mathrm{C}$ maupun suhu $50^{\circ} \mathrm{C}$. Kelarutan suatu bahan dipengaruhi oleh kadar airnya, semakin tinggi kadar air maka semakin rendah kelarutan suatu bahan. Kelarutan produk pada suhu $50^{\circ} \mathrm{C}$ masih lebih tinggi dibandingkan dengan suhu $4^{0} \mathrm{C}$ dan $25^{\circ} \mathrm{C}$. Hal ini dapat terjadi karena bubuk pewarna alami pada suhu $50^{\circ} \mathrm{C}$ terjadi pemanasan sehingga kadar air yang terdapat pada produk tidak sebanyak pada suhu $4^{0} \mathrm{C}$ dan suhu $25^{\circ} \mathrm{C}$. Menurut Ernawati (2010) semakin tinggi kadar air maka semakin rendah kelarutan suatu bahan karena produk cenderung membentuk butiran yang lebih besar tetapi tidak porous.

\section{Warna}

Hasil pengujian stabilitas untuk parameter warna bubuk pewarna alami dapat dilihat pada Tabel 4 menunjukkan bahwa semakin lama penyimpanan maka warna yang dihasilkan semakin pudar walaupun tidak signifikan perubahannya, baik bubuk pewarna alami yang disimpan pada suhu $4^{0} \mathrm{C}$, suhu $25^{\circ} \mathrm{C}$ maupun suhu $50^{\circ} \mathrm{C}$. Hal ini disebabkan semakin lama penyimpanan maka zat warna pada bubuk pewarna alami semakin menurun dan berbanding lurus dengan semakin menurunnya total antosianin yang terdapat pada produk. Menurut Harborne (2005) degradasi antosianin terjadi tidak hanya selama ekstraksi dari jaringan tumbuhan tetapi juga selama proses dan penyimpanan.

Tabel 4 Uji stabilitas warna bubuk pewarna alami terhadap suhu

\begin{tabular}{|c|c|c|c|c|c|c|}
\hline \multirow{3}{*}{$\begin{array}{c}\text { Hari ke- } \\
0\end{array}$} & \multicolumn{6}{|c|}{ Warna ( $\left.{ }^{0} \mathrm{Hue}\right)$} \\
\hline & \multicolumn{2}{|c|}{ Suhu $4^{0} \mathrm{C}$} & \multicolumn{2}{|c|}{ Suhu $25^{\circ} \mathrm{C}$} & \multicolumn{2}{|c|}{ Suhu $5^{0} \mathrm{C}$} \\
\hline & 27,25 & Merah & 27,25 & Merah & 27,25 & Merah \\
\hline 2 & 22,55 & Merah & 25,77 & Merah & 25,87 & Merah \\
\hline 4 & 22,18 & Merah & 17,76 & Merah-ungu & 22,57 & Merah \\
\hline 6 & 12,44 & Merah-ungu & 14,67 & Merah-ungu & 14,32 & Merah-ungu \\
\hline 8 & 10,06 & Merah-ungu & 12,68 & Merah-ungu & 14,58 & Merah-ungu \\
\hline 10 & 2,78 & Merah-ungu & 2,10 & Merah-ungu & 8,48 & Merah-ungu \\
\hline
\end{tabular}


Keterangan :

${ }^{0}$ Hue $=342^{0}-18^{0}$ (merah keunguan)

${ }^{0}$ Hue $=18^{0}-54^{0}$ (merah) (Hutching 1999)

\section{Stabilitas terhadap pH}

Hasil pengujian stabilitas terhadap $\mathrm{pH}$ untuk parameter total antosianin dan warna bubuk pewarna alami dapat dilihat pada Tabel 5.

\section{Total Antosianin}

Berdasarkan Tabel 5 dapat dilihat bahwa pada buffer $\mathrm{pH} 3, \mathrm{pH} 5$, dan $\mathrm{pH} 7$ menunjukkan semakin lama penyimpanan maka total antosianin semakin menurun namun masih menunjukkan kondisi stabil. Total antosianin pada buffer $\mathrm{pH} 3$ lebih tinggi

dibandingkan perlakuan buffer lainnya. Hal ini disebabkan antosianin dapat stabil pada kondisi asam dengan $\mathrm{pH}$ 3,5 sehingga tidak mengalami degradasi antosianin yang cukup besar. Faktor $\mathrm{pH}$ ternyata tidak hanya mempengaruhi warna antosianin tapi juga mempengaruhi stabilitasnya. Antosianin lebih stabil dalam larutan asam dibandingkan dalam larutan basa (Markakis 1992). Penurunan total antosianin pada setiap perlakuan tidak terlalu signifikan sehingga masih menunjukkan kondisi stabil hingga hari ke-10.

Tabel 5 Uji stabilitas bubuk pewarna alami terhadap pH

\begin{tabular}{ccccccccc}
\hline \multirow{2}{*}{$\begin{array}{c}\text { Hari } \\
\text { ke- }\end{array}$} & \multicolumn{2}{c}{ Total Antosianin (mg/g bahan) } & \multicolumn{4}{c}{ Warna ( } & ('Hue) \\
\hline 0 & 0,581 & 0,581 & 0,581 & 0,581 & 27,25 & 27,25 & 27,25 & 27,25 \\
2 & 0,450 & 0,392 & 0,371 & 0,306 & 43,16 & 43,56 & 44,27 & 44,61 \\
4 & 0,442 & 0,383 & 0,370 & 0,294 & 42,88 & 42,54 & 44,28 & 43,76 \\
6 & 0,431 & 0,380 & 0,366 & 0,293 & 30,93 & 34,06 & 34,42 & 33,00 \\
8 & 0,422 & 0,377 & 0,350 & 0,289 & 33,70 & 30,87 & 33,10 & 30,93 \\
10 & 0,416 & 0,375 & 0,347 & 0,238 & 19,85 & 24,67 & 19,77 & 18,38 \\
\hline
\end{tabular}

Keterangan :

${ }^{0}$ Hue $=18^{0}-54^{0}($ merah $)$ (Hutching 1999)

\section{Warna}

Berdasarkan Tabel 5 menunjukkan bahwa warna bubuk pewarna alami pada perlakuan beberapa $\mathrm{pH}$ menghasilkan warna merah. Semakin lama penyimpanan maka warna merah yang dihasilkan akan semakin pudar walaupun tidak signifikan perubahannya, baik bubuk pewarna alami yang disimpan pada $\mathrm{pH} 3, \mathrm{pH} 5, \mathrm{pH} 7$ maupun $\mathrm{pH}$ 9. Hal ini disebabkan semakin lama penyimpanan maka zat warna pada bubuk pewarna alami semakin menurun. Sesuai dengan semakin menurunnya total antosianin yang terdapat pada produk. Warna produk pada $\mathrm{pH} 3$ masih lebih pekat dibandingkan dengan $\mathrm{pH} 5, \mathrm{pH} 7$ dan $\mathrm{pH} 9$ walaupun perbedaannya tidak terlalu signifikan. Hal ini disebabkan sifat antosianin yang stabil pada kondisi asam dengan $\mathrm{pH} 3,5$. Menurut Lydia et al. (2001), semakin rendah nilai $\mathrm{pH}$ maka warna konsentrat semakin merah dan stabil atau jika $\mathrm{pH}$ semakin mendekati satu maka zat warna semakin stabil. Reaksi-reaksi yang terjadi pada $\mathrm{pH}$ tinggi umumnya mengakibatkan terjadinya kerusakan warna.

Pengujian stabilitas bubuk pewarna alami menunjukkan terjadinya peningkatan kadar air, penurunan total antosianin, penurunan kelarutan dan warna selama 10 hari penyimpanan walaupun perubahannya tidak signifikan. Berdasarkan uji stabilitas tersebut dapat disimpulkan bahwa bubuk pewana alami lebih stabil pada kondisi 
cahaya gelap, suhu penyimpanan $4^{0} \mathrm{C}$, dan pada $\mathrm{pH} 3$.

\section{KESIMPULAN}

Pembuatan bubuk pewarna alami dari daun bayam merah melalui beberapa tahapan diantaranya yaitu sortasi, penimbangan, pencucian, penirisan, penghancuran daun bayam merah dengan penambahan pelarut, penyaringan I, penambahan maltodekstrin, pengadukan, sentrifugasi, penyaringan II, dan pengeringan dengan vacuum dryer. Pembuatan bubuk pewarna alami dari daun bayam merah sebagai perlakuan terbaik menggunakan jenis pelarut akuades+asam sitrat 5\% dan penambahan konsentrasi maltodekstrin sebesar $15 \%$. Perlakuan ini menghasilkan rendemen sebesar 15,69\%, kadar air 4,36\%, total antosianin $0,587 \mathrm{mg} / \mathrm{g}$ bahan, kelarutan $99,00 \%$, dan nilai ${ }^{0} \mathrm{Hue} 6,34$ (merah keunguan). Uji stabilitas selama 10 hari menunjukkan bahwa bubuk pewana alami lebih stabil pada kondisi cahaya gelap, suhu penyimpanan $4^{0} \mathrm{C}$, dan pada $\mathrm{pH} 3$.

\section{SARAN}

Perlu dilakukan penelitian lebih lanjut terkait aplikasi bubuk pewarna alami misalnya pada produk pangan sebagai pewarna makanan alami.

\section{DAFTAR PUSTAKA}

Armanzah RS, Hendrawati TY. 2016. Pengaruh waktu maserasi zat antosiann sebagai pewarna alami dari ubi jalar ungu (Ipomoea batatas L.Poir). Seminar Nasional Sains dan Teknologi 2016. Jakarta (ID): Universitas Muhammadiyah Jakarta.

Eko W. 2008. Preparasi Pewarna Bubuk Merah Alami Berantioksidan dari Ekstrak Bunga Rosella serta Aplikasinya pada Produk Pangan.
[Skripsi]. Malang (ID): Universitas Brawijaya.

Endang SS, Prasetyastuti. 2010. Pengaruh pemberian juice lidah buaya (Aloe vera L) terhadap kadar lipis peroksida (MDA) pada tikus putih jantan hiperlipidemia. Jurnal Farmasi Kedokteran. 3(1): 353-362.

Ernawati S. 2010. Stabilitas sediaan bubuk pewarna alami dari rosela (Hibiscus sabdariffa L.) yang diproduksi dengan metode spray drying dan tray drying [Skripsi]. Bogor (ID): Institut Pertanian Bogor.

Francis FJ. 1999. Amaranthus betacyanin pigments applied in model food sistem. Jurnal Food Science. 64(5): 869-873.

Gonnissen Y, Remon JP, Vervaet C. 2008. Effect of maltodextrin and supedisintegrant in directly compressible powder mixtures prepared via co-spray drying. European Journal of Pharmaceutics and Biopharmaceutics. 68: 277-282.

Hall CW. 1980. Drying and Storage of Agricultural Crops. AVI Wesport, Connecticut.

Harborne. 2005. Encyclopedia of Food and Color Additives. CRC Press, Inc. New York.

Hayati EK, Budi US, Hermawan R. 2012. Konsentrasi total senyawa antosianin ekstrak kelopak bunga rosella (Hibiscus sabdariffa L.): pengaruh temperatur dan pH. Jurnal Kimia. 6(2): 138-147.

Hutching JB. 1999. Food Color and Appearance. Maryland (US): Aspen Publisher Incorporation.

Lydia, Simon B, Widjanarko, Susanto T. 2001. Ekstraksi dan karakterisasi pigmen dari kulit buah rambutan 
(Nepheliumla ppaceumy). Jurnal Teknologi Pangan dan Gizi. 2(1): 1-16.

Markakis P. 1982. Anthocyanins as Food Additives. Di dalam Anthocyanins as Food Colors. Academic Press. New York.

Ovando AC, Hernandez MLP, Rodriguez JA, Vidal CAG. 2009. Chemical studies of anthocyanins. Journal $f$ Food Chemistry. 113: 859-871.

Pentury MH, Nursyam H, Harahap N, Soemarno. 2013. Karakterisasi maltodekstrin dari pati hipokotil mangrove (Bruguiera gymnorrhiza) menggunakan beberapa metode hidrolisis enzim. Indonesian Green Technology Journal. 2(1): 53-60.

Sutanto GN. 2007. Pengeringan bahan pangan [skripsi]. Bandung (ID): Institut Teknologi Bandung.

Tama JB, Kumalaningsih S, Mulyadi AF. 2014. Studi Pembuatan Bubuk Pewarna Alami Dari Daun Suji (Pleomele Angustifolioa N.E.BR.) Kajian Konsentrasi Maltodekstrin dan
$\mathrm{MgCO}_{3}$. Jurnal Industria. 3(1): 73-82.

Utomo D. 2013. Pembuatan serbuk effervescent murbei (Morus alba L.) dengan kajian konsentrasi maltodekstrin dan suhu pengering. Jurnal Teknologi Pangan. 5(1): 49-69.

Wibawanto NR, Ananingsih VK, Pratiwi R. 2014. Produksi serbuk pewarna alami bit merah (Beta vulgaris L.) dengan metode oven drying. Prosiding SNST ke-5 Fakultas Teknik Universtas Wahid Hasyim Semarang.

Wiersema SG. 1989. Storage Requirements for Potato Tubers. International Potato Center (CIP), Bangkok, Thailand.

Winarno FG. 2002. Kimia Pangan dan Gizi. Jakarta (ID): Gramedia Pustaka Utama.

Wulansari A, Prasetyo DB, Lejaringtyas M, Hidayat A, Anggarini S. 2012. Aplikasi dan Analisis Kelayakan Pewarna Bubuk Merah Alami Berantioksidan dari Ekstrak Biji Buah Pinang (Areca catechu) sebagai Bahan Pengganti Pewarna Sintetik pada Produk Pangan. Jurnal Industria. 1(1): 1-9. 
Metode Pembuatan bubuk pewarna alami

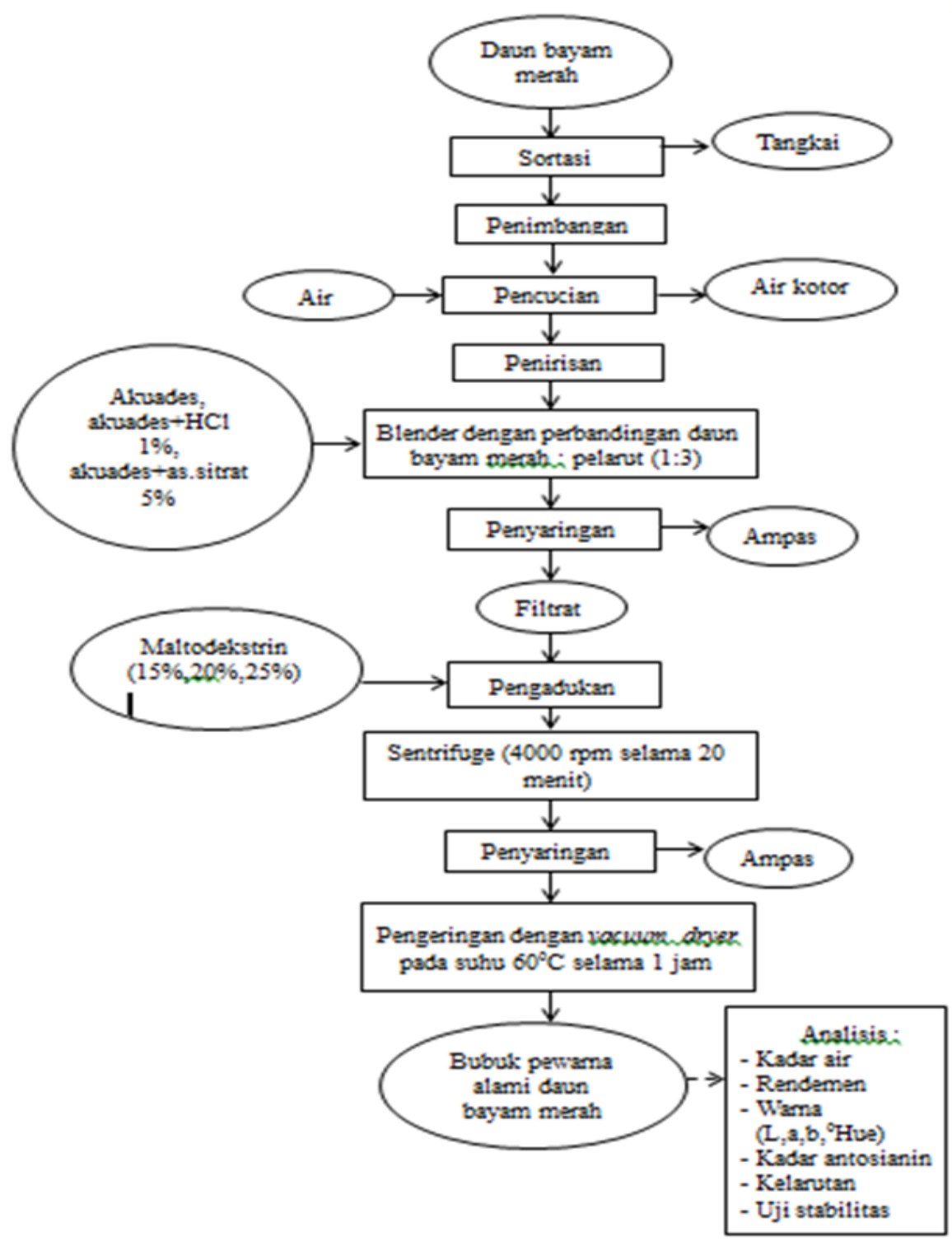

Gambar 5 Diagram alir pembuatan bubuk pewarna alami daun bayam merah 